\title{
Oxidant / antioxidant status and thyroid function tests in hypertensive patients treated by captopril or valsartan
}

\author{
Shamil H. Othman, Imad A. Thanoon \\ Department of Pharmacology, College of Medicine, University of Mosul.
}

(Ann. Coll. Med. Mosul 2012; 38 (2): 62-67).

Received: $30^{\text {th }}$ Feb. 2011; Accepted: $9^{\text {th }}$ Jul. 2012.

\begin{abstract}
Objectives: To assess, the oxidant / antioxidant status and thyroid function tests in newly diagnosed hypertensive patients and the effect of therapy with captopril or valsartan for 2 months on these parameters in comparison to healthy control subjects.

Methods: This study was conducted in Ibn-Sina Teaching Hospital, Consultative Clinic for Internal Medicine in Mosul city, from Jan. to Dec. 2008. Patients with certain criteria were included in this study. Blood samples were taken from the patients and assay of serum level of malondialdehyde (MDA), total antioxidant status (TAS) and thyroid hormones; [total triiodothyronine $\left(\mathrm{T}_{3}\right)$, total thyroxine $\left(\mathrm{T}_{4}\right)$ and thyroid stimulating hormone (TSH)] were done. They then started to receive either valsartan in the first group or captopril in the second group for 2 months after which another set of blood samples were taken and assayed for the same parameters mentioned above, were done. Forty apparently healthy subjects were also included in this study. They were recruited as a control group.

Results: Before starting therapy newly diagnosed hypertensive patients, had a significantly higher MDA serum levels and a significantly lower TAS, with non-significant differences in the levels of thyroid hormones $\left(\mathrm{TT}_{3}, \mathrm{TT}_{4} \& \mathrm{TSH}\right)$ in comparison to healthy controls. After 2 months of treatment with either captopril or valsartan, there was a significant decrease in MDA serum levels and a significant increase in TAS levels with non-significant effects on thyroid hormonal levels in comparison to pre-therapy stage.

Conclusion: Captopril and valsartan therapy improves oxidant / antioxidant status and carry no adverse effects on thyroid function in newly diagnosed patients with mild to moderate hypertension.
\end{abstract}

Keywords: Total antioxidant status, malondialdehyde, thyroid function tests hypertensive patients, captopril, valsartan.

الخلاصة

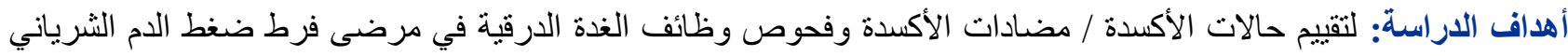
المشخصين حديثا، وتأثير إعطاء الكابتوبريل أو الفالزرتان لنشهرين على هذه المفردات بالمقارنة مع مجموعة ضبط من الأصحاء ظاهريا.

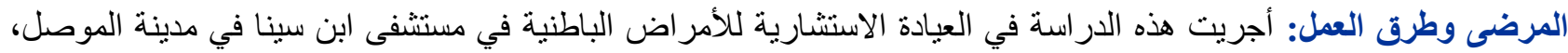

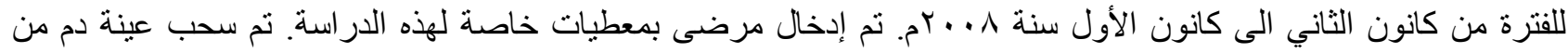

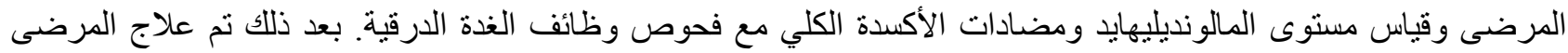

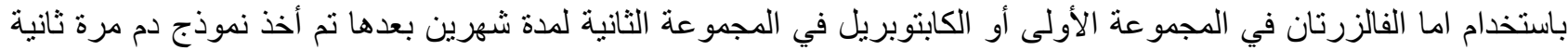

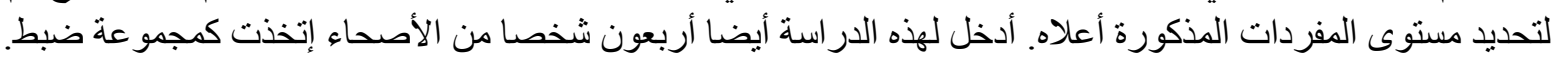

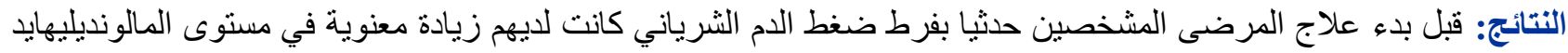

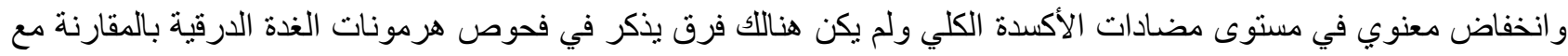

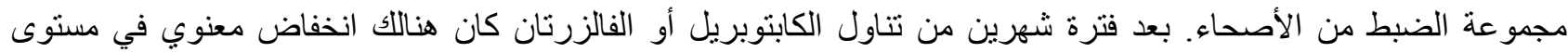




$$
\begin{aligned}
& \text { المالونديليهايد وارتفاع معنوي في مستوى مضادات الأكسدة الكلي مع تأثير غير معنوي على مستوى هرمونات الغدة الدرقية }
\end{aligned}
$$

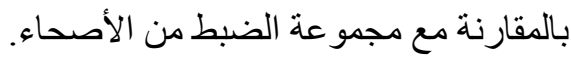

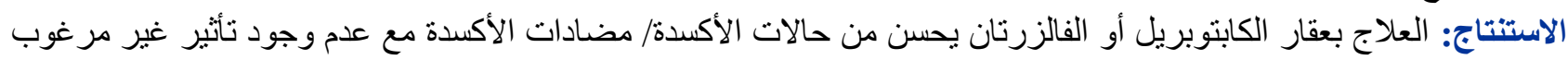

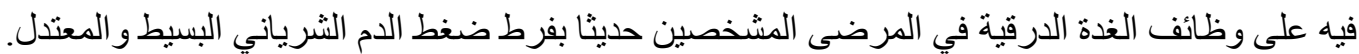

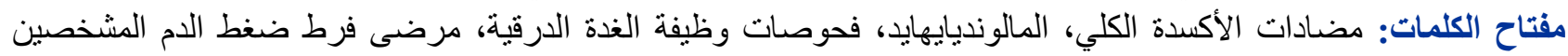

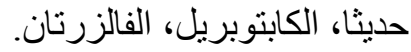

I humans, hypertension is considered as state

of oxidative stress (OS) that can contribute to the development of atherosclerosis and other hypertension-induced organ damage. ${ }^{(1)}$ It was noted that there was an over production of oxygen free radicals, occurring in hypertensive patients. ${ }^{(2)}$ Assessment of antioxidant activities in hypertensive subjects indicate an excessive amount of reactive oxygen species (ROS) and a reduction of antioxidant mechanism activity in both blood as well as in several other cellular systems. ${ }^{(3)}$

A large number of antihypertensive drugs are available including captopril (a potent angiotensin converting enzyme inhibitor ACEI) and valsartan (a specific angiotensin II antagonist) that are found to be more prescribed drugs for hypertenive patients ${ }^{(4)}$. Pharmacologic treatment of hypertension can cause clinically significant alterations in endocrine functions through effects on different hormones including thyroid hormones. ${ }^{(5)}$ No data were available concerning the effects of captopril and valsartan on thyroid function tests.

The aim of this study was to assess the oxidant/ antioxidant status (through measuring serum MDA and total antioxidant status) and thyroid function tests $\left(\mathrm{TT}_{3}, \mathrm{TT}_{4}\right.$ and $\left.\mathrm{TSH}\right)$, in newly diagnosed hypertensive patients, before starting therapy and two months after either captopril or valsartan in comparison to healthy control subjects.

\section{PATIENTS AND METHODS}

This study was conducted in Ibn-Sina Teaching Hospital- Consultative Clinic for Internal Medicine in Mosul City, from January to December 2008. To achieve the aim of the present study, a randomized control comparative trial, (open label design) was adopted. This trial began with a defined population that was randomized to receive either valsartan or captopril treatment, and patients were followed in each group for 2 months period.

Patients with the following criteria were included in this study: newly diagnosed mild to moderate essential hypertension, body mass index $<30$, non-smokers, with no history of diabetes mellitus, renal or hepatic diseases, no left ventricular hypertrophy or dysfunction on electrocardiography or echocardiography, no history of thyroid disease and for female patients, not pregnant or lactating. From patients who were eligible to the study blood samples were withdrawn and assayed for serum MDA, TAS and thyroid hormones $\left(\mathrm{TT}_{3}, \mathrm{TT}_{4}, \mathrm{TSH}\right)$. Then they started to receive either valsartan (Univan, Unichima pharmaceutical, Syria), in a dose of 80 to $160 \mathrm{mg}$ per day in the first group that consisted of 50 patients completed the study (out of 68 patients); or captopril (Rilcaptone, Medochemie Ltd, Cyprus) in a dose of 25 to 100 $\mathrm{mg}$ per day in the second group that consisted of 50 patients, completed the follow-up study (out of 63 patients). Patients in both groups were followed for 2 months period; by the end of this period a second set of blood samples were taken and assayed for the same parameters mentioned above. Forty apparently healthy subjects were also included in this study. They were not hypertensive and free from other diseases, were recruited as a control group. They were judged free of any disease by history, clinical examination, electrocardiography and routine laboratory data. From the subjects in the control group blood samples withdrawn and assayed for serum MDA, TAS and thyroid function tests $\left(\mathrm{TT}_{3}, \mathrm{TT}_{4}, \mathrm{TSH}\right)$.

Serum MDA level was estimated using TBA assay method. ${ }^{(6)}$ Total antioxidant status (TAS) was measured using Randox TAS Kit (UK), according to the method described by Miller et al. ${ }^{(7)}$

The determination of $\mathrm{TT}_{3}$ and $\mathrm{TT}_{4}$ were done by using a commercial kits (Immunotech-France) depending on radioimmunoassay 
technique. ${ }^{(8)}$ The determination of TSH concentration was done using a commercial kit (Immunotech-France) based on immunoradiometric assay (IRMA) technique. ${ }^{(8)}$

\section{Statistical analysis}

Standard statistical methods were used to determine the mean and standard deviation. Unpaired t-test was used to compare the results of various biochemical parameters of hypertensive patients with the controls. Paired t-test was used to compare the results of various biochemical parameters between hypertensive patients before and after therapy in each group. P-value $\leq 0.05$ was considered statistically significant. ${ }^{(9)}$

\section{RESULTS}

Table 1 shows the characteristics of the patients and control subjects.

Table 2, shows that serum levels of MDA were statistically higher $(P<0.001)$ in hypertensive patients allocated to valsartan group before starting therapy $(2.12 \pm 0.4 \mu \mathrm{mol} / \mathrm{L})$, whereas, serum level of TAS $(1.13 \pm 0.15 \mathrm{mmol} / \mathrm{L})$ were significantly lower $(P<0.001)$ in such hypertensive group in comparison to controls $(0.72 \pm 0.16$ $\mu \mathrm{mol} / \mathrm{L} ; 1.70 \pm 0.18 \mathrm{mmol} / \mathrm{L}$ respectively).

After 2 months of valsartan therapy there was a significant decrease $(P<0.001)$ in serum MDA levels with significant increase $(P<0.001)$ in serum TAS levels, but the levels of the two markers, did not reach control values (Table 2).

Table 1. The characteristics of hypertensive patient and control groups.

\begin{tabular}{|c|c|c|c|c|c|c|c|}
\hline \multicolumn{2}{|c|}{ Groups } & \multicolumn{2}{|c|}{ Parameters } & \multicolumn{4}{|c|}{ Mean \pm SD } \\
\hline \multirow{2}{*}{\multicolumn{2}{|c|}{ Control }} & \multicolumn{2}{|c|}{ Age (yr) } & \multicolumn{4}{|c|}{$47.10 \pm 10.3$} \\
\hline & & \multicolumn{2}{|c|}{ BMI $\left(\mathrm{kg} / \mathrm{m}^{2}\right)$} & \multicolumn{4}{|c|}{$25.57 \pm 2.31$} \\
\hline \multirow{2}{*}{\multicolumn{2}{|c|}{ Captopril }} & \multicolumn{2}{|c|}{ Age (yr) } & \multicolumn{4}{|c|}{$51.24 \pm 9.35$} \\
\hline & & \multicolumn{2}{|c|}{$\mathrm{BMI}\left(\mathrm{kg} / \mathrm{m}^{2}\right)$} & \multicolumn{4}{|c|}{$25.84 \pm 1.46$} \\
\hline \multirow{2}{*}{\multicolumn{2}{|c|}{ Valsartan }} & \multirow{2}{*}{\multicolumn{2}{|c|}{$\frac{\text { Age }(\mathrm{yr})}{\mathrm{BMI}\left(\mathrm{kg} / \mathrm{m}^{2}\right)}$}} & \multicolumn{4}{|c|}{$48.32 \pm 11.34$} \\
\hline & & & & \multicolumn{4}{|c|}{$26.34 \pm 2.16$} \\
\hline & & \multicolumn{2}{|c|}{ Control } & \multicolumn{2}{|c|}{ Captopril } & \multicolumn{2}{|c|}{ Valsartan } \\
\hline & & No. & $\%$ & No. & $\%$ & No. & $\%$ \\
\hline \multirow{3}{*}{$\underset{\infty}{\infty}$} & Male & 20 & 50.0 & 30 & 60.0 & 25 & 50.0 \\
\hline & Female & 20 & 50.0 & 20 & 40.0 & 25 & 50.0 \\
\hline & Total & 40 & 100 & 50 & 100 & 50 & 100 \\
\hline
\end{tabular}

Table 2. Effect of valsartan therapy on MDA and TAS concentration in hypertensive patients.

\begin{tabular}{|l|c|c|c|}
\hline Parameters & Groups & Mean \pm SD & $\boldsymbol{P}$ \\
\hline \multirow{2}{*}{ MDA $(\mu \mathrm{mol} / \mathrm{L})$} & Before & $2.12 \pm 0.4$ & \multirow{2}{*}{$<0.001$} \\
\cline { 2 - 3 } & After & $1.84 \pm 0.38$ & \\
\hline \multirow{2}{*}{ TAS $(\mathrm{mmol} / \mathrm{L})$} & Before & $1.13 \pm 0.15$ & \multirow{2}{*}{$<0.001$} \\
\cline { 2 - 3 } & After & $1.38 \pm 0.17$ & \\
\hline
\end{tabular}

Using paired t-test.

There was also a significantly higher serum MDA levels $(2.16 \pm 0.47 \mu \mathrm{mol} / \mathrm{L}) \quad(P<\quad 0.01) \quad$ in hypertensive patients allocated to captopril group, before starting therapy, whereas serum TAS levels $(1.21 \pm 0.17 \mathrm{mmol} / \mathrm{L})$ were significantly lower $(P<$ 0.001 ) in such hypertensive group in comparison to controls $(0.72 \pm 0.16 \mu \mathrm{mol} / \mathrm{L} ; 1.70 \pm 0.18 \mathrm{mmol} / \mathrm{L}$ respectively).

After 2 months of captopril therapy, there was a significant decrease $(P<0.001)$ in the serum MDA levels with a significant increase in TAS levels $(\mathrm{P}<0.001)$ in such patients in comparison to pretherapy stage, but still values were significantly different from control value (Table 3).

There was insignificant differences in the mean serum levels of thyroid hormones $\left(\mathrm{TT}_{3}, \mathrm{TT}_{4}, \mathrm{TSH}\right)$ between hypertensive patients allocated to valsartan group before starting therapy $(2.06 \pm$ $0.52 \mathrm{nmol} / \mathrm{L} ; 115.62 \pm 23.9 \mathrm{nmol} / \mathrm{L} ; 2.28 \pm 0.75$ $\mathrm{mIU} / \mathrm{L})$ and the controls $(2.10 \pm 0.53 \mathrm{nmol} / \mathrm{L}$; $113.15 \pm 25.4 \mathrm{nmol} / \mathrm{L} ; 2.31 \pm 0.54 \mathrm{mIU} / \mathrm{L})$, with insignificant alteration in these parameters after 2 months of therapy as compared to pre-therapy stage (Table 4).

There were also insignificant differences in the mean serum levels of thyroid hormones between hypertensive patients allocated to captopril group, before starting therapy and the controls, and that the administration of captopril for two months caused insignificant changes in the thyroid hormones as compared to pre-therapy stages (Table 5).

Table 3. Effect of captopril therapy on MDA and TAS concentrations in hypertensive patients.

\begin{tabular}{|l|c|c|c|}
\hline Parameters & Groups & Mean \pm SD & $\boldsymbol{P}$ \\
\hline \multirow{2}{*}{ MDA $(\mu \mathrm{mol} / \mathrm{L})$} & Before & $2.16 \pm 0.47$ & \multirow{2}{*}{$<0.001$} \\
\cline { 2 - 3 } & After & $1.83 \pm 0.41$ & \\
\hline \multirow{2}{*}{ TAS $(\mathrm{mmol} / \mathrm{L})$} & Before & $1.2 \pm 10.17$ & \multirow{2}{*}{$<0.001$} \\
\cline { 2 - 3 } & After & $1.44 \pm 0.18$ & \\
\hline
\end{tabular}

Using paired t-test. 
Table 4. Effect of valsartan therapy on thyroid function tests in hypertensive patients.

\begin{tabular}{|l|c|c|c|}
\hline Parameters & Groups & Mean \pm SD & \multirow{2}{*}{$\boldsymbol{P}$} \\
\hline \multirow{2}{*}{$\mathrm{TT}_{3}(\mathrm{nmol} / \mathrm{L})$} & Before & $2.06 \pm 0.52$ & \multirow{2}{*}{ NS } \\
\cline { 2 - 3 } & After & $2.04 \pm 0.49$ & \\
\hline \multirow{2}{*}{$\mathrm{TT}_{4}(\mathrm{nmol} / \mathrm{L})$} & Before & $115.62 \pm 23.9$ & \multirow{2}{*}{ NS } \\
\cline { 2 - 3 } & After & $114.56 \pm 23.44$ & \\
\hline \multirow{2}{*}{$\mathrm{TSH}(\mathrm{mIU} / \mathrm{L})$} & Before & $2.28 \pm 0.75$ & \multirow{2}{*}{ NS } \\
\cline { 2 - 3 } & After & $2.29 \pm 0.76$ & \\
\hline
\end{tabular}

NS = Not significant using paired t-test.

Table 5. Effect of captopril therapy on thyroid function tests in hypertensive patients.

\begin{tabular}{|l|c|c|c|}
\hline Parameters & Groups & Mean \pm SD & \multirow{2}{*}{$\boldsymbol{P}$} \\
\hline \multirow{2}{*}{$\mathrm{TT}_{3}(\mathrm{nmol} / \mathrm{L})$} & Before & $2.25 \pm 0.45$ & \multirow{2}{*}{ NS } \\
\cline { 2 - 3 } & After & $2.26 \pm 0.48$ & \\
\hline \multirow{2}{*}{$\mathrm{TT}_{4}(\mathrm{nmol} / \mathrm{L})$} & Before & $116.10 \pm 18.13$ & \multirow{2}{*}{$\mathrm{NS}$} \\
\cline { 2 - 3 } & After & $115.91 \pm 19.53$ & \\
\hline \multirow{2}{*}{$\mathrm{TSH}(\mathrm{mlU} / \mathrm{L})$} & Before & $2.41 \pm 0.70$ & \multirow{2}{*}{$\mathrm{NS}$} \\
\cline { 2 - 3 } & After & $2.42 \pm 0.74$ & \\
\hline
\end{tabular}

NS = Not significant using paired t-test.

\section{DISCUSSION}

The defense system against ROS harm, includes a variety of enzymatic and Non-enzymatic antioxidants like vitamin $C, E$ and $A$, superoxide dismutase, catalase, glutathione peroxidase, urate, ferritin, ceruloplasmin etc. ${ }^{(10)}$ In this study TAS was assayed according to Jacob ${ }^{(11)}$ as it gives more appropriate means of assessing antioxidant system function than measurement of individual antioxidant components.

In hypertension, one of the most important mechanisms determining endothelial dysfunction is the production of oxidative stress; this possibility was indirectly explored by measuring plasma parameters of oxidative stress. ${ }^{(12)}$

Malondialdehyde (MDA), is the most generally used index of lipid peroxidation in the appreciation of the role of OS in diseases and it is often assayed with thiobarbituric acid procedure, (13) which is used in this study.

In the present study, it was noted that serum MDA levels were significantly higher and serum TAS levels were significantly lower in newly diagnosed hypertensive patients when compared to healthy controls.

In addition, the administration of valsartan or captopril to such patients for two months was associated with a significant reduction in MDA levels and a significant increase in TAS levels, but still did not reach the control values.

The elevated MDA levels and reduced antioxidant capacity in newly diagnosed hypertensive patients can be explained, based on the fact that excess ROS generated in hypertension could result in a decrease in the antioxidant enzymatic activities in the plasma and peripheral mononuclear cells. Moreover even though the increment in the ROS may up-regulate the antioxidant enzymes, under higher amount of pure oxygen or related species, consumption by ROS can overcome the increased production leading to the low activity observed. ${ }^{(3)}$

Dandona et $\mathrm{al}^{\left({ }^{(14)}\right.}$ and in accordance with our results reported that valsartan at modest dose exerted a profound and rapid ROS and inflammation suppressive effects that may be relevant to its potential beneficial effects in several diseases including hypertension. Osamah et al, ${ }^{(15)}$ also reported that valsartan therapy in hypercholesterolemic hypertensive patients had an additive antioxidant effect to that of fluvastatin therapy. Yang et $a l,{ }^{(16)}$ concluded that valsartan showed concentration dependent inhibition of ROS generation in polymorphnuclear leukocytes.

Other similar members of angiotensin receptor blockers were studied by Koh et al. ${ }^{(17)}$ They reported that candesartan, irbesartan and losartan significantly reduced plasma levels of MDA.

Rodriguez- Iturbe et al, (18) suggested that by attenuating the angiotensin-mediated upregulation of nicotinamide adenine diphosphate (NAD (p)H oxidase), angiotensin type one-receptor blockers exerts an antioxidant action that contribute to its antihypertensive and renal protective properties.

Concerning captopril therapy, Chopra et al, ${ }^{(19)}$ reported that the presence of sulfhydryl on ACEls resulted in effective free radical scavenging. These findings also supported by the study of Suzuki et $\mathrm{al}^{(20)}$ who reported that both captropril and a sulfhydryl containing amino acid derivatives without angiotensin converting enzyme inhibiting properties significantly improved survival and myocardial injury by scavenging free radicals, but they reduce the expression of SOD-mRNA.

In contrast to these findings, Lapenna et al, ${ }^{(21)}$ reported that captopril had a prooxidant properties and thus, it can not be considered simply as an antioxidant drug. 
In their recent research work, kiran et al, (2) reported a significant decrease in reduced glutathione (GSH) and TAS in untreated hypertensive patients and that ramipril (an ACEI) and losartan (angiotensin-receptor blocker) bring about a significant elevation in the levels of $\mathrm{GSH}$ and TAS. They concluded that both drugs were having a significant protection against oxidative stress.

The possible effects of drug therapy on the results of thyroid function tests must always be considered in decisions regarding patient care. ${ }^{(22)}$

Thyroid disorders are usually associated with either low plasma renin as in the case of hypothyroidism or hyperactivity of renin angistensin - aldosterone system (RAAS) in hyperthyroidism. Thus, plasma renin activity and plasma levels of angistensin II with aldosterone are directly related to plasma levels of thyroid hormones. ${ }^{(23)}$ Thyroid hormone, may cause down regulation of the angiotensin-1 receptor expression at both transcriptional and post-transcriptional levels and attenuate the biological function of angiotensin II. This may suggest that thyroid hormones could be a negative regulator of RAAS. ${ }^{(24)}$

The effect of antihypertensive drugs on thyroid functions was studied by many researchers. Kristensen and Weeke, ${ }^{(25)}$ reported that propranolol therapy in doses of $80-480 \mathrm{mg} / \mathrm{d}$ for 30 days period, in 15 euthyroid hypertensive patients causes the total and free T3 as well as TSH concentration to be unchanged with an average increase in total and T4 concentration, and they concluded that propranolol -induced decreased degradation of $\mathrm{T} 4$ levels. Velasco et $\mathrm{al},{ }^{(26)}$ concluded that prazocin $1-4 \mathrm{mg} / \mathrm{d}$ in 19 patients with hypertension for 12 wks causes increases in TSH and T4 with decrease in T3 levels, but all values remained within the normal ranges. Gumbatov et al, (27) reported that nadolol monotherapy in 20 males with stage 2 hypertension and in a dose of $40-160 \mathrm{mg} / \mathrm{d}$ causes insignificant changes in the mean values of TSH and T4 levels, but causes a decrease in T3 concentration at its high baseline value and in a dose greater than $40 \mathrm{mg} /$ day.

To the best of our knowledge, the present study was the first demonstration that valsartan and captopril have no adverse effects on thyroid function as reflected by the levels of $\mathrm{TT}_{3}, \mathrm{TT}_{4}$ and TSH in newly diagnosed hypertensive patients after 2 months of therapy in comparison to healthy controls.

In conclusion, captopril (ACEI) and valsartan (angiotensin receptor blocker) therapy improve oxidant / antioxidant balance, and carry no adverse effects on thyroid function in newly diagnosed patients with mild to moderate hypertension.

\section{REFERENCES}

1. Grossman E. Does increased oxidative stress cause hypertension. Diabetes Care 2008;31(12):51855189.

2. Kiran VU, Rajaiah NV, Krishna DR, Reddy YN. Effect of Losartan and ramipril on oxidative stress and antioxidant status in south Indian hypertensive patients. Int J Pharmacol 2010;6:916-920.

3. Redon J,Oliva MR, Tormos C, Giner V, Chaves J, Iradi $A$, et al. Antioxidant activities and oxidative stress byproducts in human hypertension. Hypertension 2003;41:1096-1101.

4. $\mathrm{Gu} \mathrm{Q}$, Paulose-Ram R, Dillon C, Burt V. Antihypertensive medication use among US adults with hypertension. Circulation 2006;113:213-221.

5. Brass EP. Effects of antihypertensive drugs on endocrine function. Drugs 1984; 27(5):447-458.

6. Buege JA, Aust SD. Thiobarbituric acid assay. Methods Enzymol 1978;52: 306-307.

7. Miller NJ, Rice-Evans C, Davies MJ, Gopinathan V, Milner A. A novel method for measuring antioxidant capacity and its application to monitoring the antioxidant status in premature neonates. Clin Sci 1993;84:407-412.

8. Cummings PJ. Immunoassay. In: Christensen $\mathrm{RH}$, Gregory LC, Johnson LJ, (eds). Appleton and Lange's outline review: Clinical Chemistry. UAS: McGraw-Hill Company; 2001.p.310-315.

9. Kirkwood BR. Essentials of medical statistics. $1^{\text {st }}$ edition. Blackwell Scientific Publication, Oxford, 1998.p:43-56.

10. Southorn PA, Powis G. Free radicals in medicine.I: chemical nature and biologic reactions. Myo Clin Proc 1988;63:381-389.

11. Jacob RA. The integrated antioxidant system. Nut Res 1995;15:755-766.

12. Ghiadoni L, Magagna A, Versari D, Kardasz I, Huang $Y$, Taddei $S$. Different effect of antihypertensive drugs on conduit artery endothelial function. Hypertension 2003:41:1281-1286.

13. Gawat S, Wardas M, Niedworok E, Wardas $P$. Malondialdehyde (MDA) as a lipid peroxidation marker. Wiad Lek 2004;57:453-455.

14. Dandona P, Kumar V, Aljada A, Ghanim H, Syed T, Hofmayer D, et al. Angiotensin II receptor blocker 
valsartan suppresses reactive oxygen species generation in leukocytes. Nuclear factor-k B, in mononuclear cells of normal subjects: evidence of an anti-inflammatory action. J Clin Endocrinol Metab 2003;88:4496-4501.

15. Osamah H, Julia S, Mira R, Michael A. Vallarta therapy has additive antioxidant effect to that of fluvastatin therapy against low-density lipoprotein oxidation: studies in hypercholesterolemic and hypertensive patients. J Cardiovasc Pharmacol 2002; 40(1):28-34.

16. Yang HY, Kao PF, Chen TH, Tomlinson B, Ko WC, Chan $P$. Effects of angiotensin II type 1 receptor antagonist valsartan on the expression of superoxide dismutase in hypertensive patients. J Clin Pharmacol 2007;47(3):397-403.

17. Koh KK, Han SH, Chung WJ, Ahn JY, Jin DK, Kim $\mathrm{HS}$, et al. Comparison of effects of losartan, irbesartan and candesartan on flow -mediated brachial artery dilation and on inflammatory and thrombolytic markers in patients with systemic hypertension. Am J Cardiol 2004;93(11): 14321435.

18. Rodriguez-Iturbe B, Zhan CD, Quiroz Y, Sindhu RK, Vaziri ND. Antioxidant-rich diet relieves hypertension and reduces renal immune infilteration in spontaneously hypertensive rates. Hypertension 2003; 41: 341-346.

19. Chopra M, Beswick $H$, Clapperton M, Dargie $H$, Smith W, McMurray J. Antioxidant effects of angiotensin-converting enzyme (ACE) inhibitors: free radical and oxidant scavenging are sulfhydryl dependent, but lipid peroxidation is inhibited by both sulfhydryl and non-sulfhydryl-containing ACE inhibitors. J Cardiovasc Pharmacol 1992;19:330340.
20. Suzuki H, Matsumori A, Matoba Y, Kyn BS, Tanaka $\mathrm{A}$, Fujita $\mathrm{J}$ et al. Enhanced expression of superoxide dismutase m-RNA in viral myocarditis: an $\mathrm{SH}$ dependent reduction of its expression and myocardia injury. J Clin Invest 1993;91: 2727-2733.

21. Lapenna D, DeGioia S, Mezzettia A, Ciofani G, Ilio C, Cuccurullo F. The prooxidant properties of captopril. Biochem Pharmacol 1995;50(1):27-32.

22. Surks MI, Sievert R. Drugs and thyroid function. N Engl J Med 1995;333(25): 1688-1694.

23. Vargas F, Moreno JM, Rodriguez-Gomez I, Wangensteen R, Osuna A, Alvarez-Guerra M, et al. Vascular and renal function in experimental thyroid disorders. Europ J Endocrinol 2006;154:197-212.

24. Fuknyama K, Ichiki T, Takeda K, Tokunou T, lino N, Masuda $S$, et al. Down-regulation of vascular angiotensin II type 1 receptors by thyroid hormones. Hypertension 2003; 41:598-603.

25. Kristensen BO, Weeke J. Propranolol-induced increment in total and free serum thyroxine in patients with essential hypertension. Clin Pharmacol Ther 1977; 22(6):864-867.

26. Velasco M, Silva H, Morillo J, Pellier R, UrbinaQuintana A, Hernandez-Pieretti O. Effect of prazosin on blood lipids and on thyroid function in hypertensive patients. Cardiovasc Pharmacol 1982;4(2):225-227.

27. Gumbatov NB, Mustafaev II, Kasumov FZ, Mamedora RN, Akhmedova ZG, Samoileuko TI. The effect of long-term treatment with nadolol on serum levels of thyroid hormones and thyrotropin in patients with hypertension. Kardiologiia 1990;30(3):62-65. 